\title{
PENGARUH PENERAPAN SISTEM E-Filing, PENGETAHUAN PERPAJAKAN DAN KESADARAN WAJIB PAJAK TERHADAP KEPATUHAN WAJIB PAJAK (Studi Pada Wajib Pajak Orang Pribadi Yang Melakukan Kegiatan Usaha Bebas di Bintaro Trade Center)
}

\author{
Ahmad Burhan Zulhazmi dan Febrian Kwarto \\ Fakultas Ekonomi dan Bisnis, Universitas Mercu Buana \\ Email: burhanzahmad@gmail.com
}

Diterima 29 April 2019, Disetujui 23 Juli 2019

\begin{abstract}
Abstrak
Penelitian ini bertujuan untuk mengetahui dan menganalisis pengaruh penerapan sistem $e$-filing, pengetahuan dan kesadaran perpajakan terhadap kepatuhan pajak. Penelitian ini menggunakan data primer yang diperoleh dari data kuesioner yang dibagikan kepada para responden wajib pajak orang pribadi yang melakukan kegiatan usaha bebas di Bintaro Trade Center (BTC). Teknik pengambilan sampel menggunakan purposive sampling. Teknik analisis menggunakan analisis regresi linier berganda dengan menggunakan SPSS versi 22 dengan tingkat signifikansi sebesar 5\%. Hasil penelitian ini menunjukkan bahwa secara simultan, variabel penerapan sistem e-filing, pengetahuan dan kesadaran perpajakan berpengaruh terhadap kepatuhan pajak. Penerapan sistem $e$-filing dan kesadaran perpajakan secara parsial berpengaruh terhadap kepatuhan pajak, sedangkan pengetahuan perpajakan secara parsial tidak berpengaruh terhadap kepatuhan pajak.
\end{abstract}

Kata Kunci : Pengetahuan Pajak, Kesadaran Pajak, Kepatuhan Pajak

\section{Abstract}

This study aims to determine and analyze the influence of the application of e-filing systems, tax knowledge, and tax awareness to tax compliance. This study uses primary data obtained from questionnaire data distributed to respondents who are required to tax individuals who carry out free business activities at the Bintaro Trade Center (BTC). The sampling technique uses purposive sampling. The analysis technique uses multiple linear regression analysis. The results of this study indicate that simultaneously, the variable implementation of e-filing systems, knowledge of taxation and awareness of taxpayers on tax rates. Application of e-filing system and awareness of taxpayers to mandatory obligations, while knowledge of taxation does not involve taxpayer obligations.

Keywords: E-filing, Tax Knowledge, Tax Awareness, Tax Compliance 


\section{PENDAHULUAN}

Pajak merupakan salah satu sumber penerimaan negara yang terbesar. Selain itu, pajak memiliki peranan penting dalam proses pembangunan sebagai upaya untuk menciptakan kesejahteraan masyarakat. Peranan pajak dapat dirasakan secara langsung maupun tidak langsung. Manfaat yang dirasakan dari pajak adalah fasilitas pendidikan, fasilitas transportasi, fasilitas kesehatan, fasilitas sarana dan prasarana umum. Pentingnya peran pajak dalam pembangunan membutuhkan peningkatan dalam penerimaan pajak.

Salah satu bentuk reformasi perpajakan yang digalakkan adalah modernisasi administrasi pelayanan pajak melalui penggunaan teknologi informasi dan komunikasi. Tentunya administrasi perpajakan sudah tidak relevan lagi menggunakan teknologi era pita kaset untuk dapat mendapatkan hasil optimal di era digital ini. Reformasi pada proses administrasi perpajakan adalah diterapkannya sistem e-filing. E-filling merupakan layanan pengisian dan penyampaian Surat Pemberitahuan Wajib Pajak yang dilakukan secara elektronik melalui website resmi Direktorat Jenderal Pajak atau melalui aplikasi yang disediakan ASP (Application Service Provider / Penyedia Jasa Aplikasi) yang telah ditunjuk oleh Direktorat Jenderal Pajak. Hal tersebut sudah mulai diwajibkan pemerintah melalui PMK-09/PMK.03/ 2018 perubahan atas PMK-243/PMK.03/2014 tentang Surat Pemeberitahuan (SPT). Di harapkan dengan adanya e-filing dapat memudahkan wajib pajak dalam menyampaikan SPT. Namun masih banyak ditemmukan wajib pajak yang belum paham terkait penggunaan e-filing.

Dalam artikel okezone.com tanggal 12 Maret 2018, Direktur Penyuluhan dan Hubungan Masyarakat (P2Humas) Ditjen Pajak Hestu Yoga Saksama mengatakan bahwa jumlah wajib pajak yang melapor sudah mencapai 4,5 juta SPT. Total SPT tahuan yang disampaikan 4,5328 juta dan 3,360 juta melalui e-filing dan e-form. Artinya masih ada sebanyak 1,168 juta yang masih melaporkan ke kantor pelayan pajak (KPP), dapat disimpulkan bahwa masih banyak masyarakat yang belum tahu atau belum paham mengenai sistem pelaporan secara online.

Kantor Pelayanan Pajak Pratama (KPP) Pondok Aren, Tangerang Selatan, terdapat 82.291 wajib pajak yang belum melaporkan Surat Pemberitahuan Tahunan (SPT). Hingga Kamis 29 Maret 2018 KPP baru menerima 40.692 WP orang dan 415 WP Badan (metrotvnews.com). Dari fenemona tersebut terlihat bahwa tingkat kesadaran masyarakat dalam memenuhi kewajiban perpajakannya masih rendah.

Pemerintah terus berupaya untuk meningkatkan kepatuhan wajib pajak salah satunya dengan mengeluarkan Peraturan Presiden Republik Indonesia Nomor 40 Tahun 2018 tentan Pembaruan Sistem Administrasi Perpajakan. Dengan adanya pembaruan sistem administrasi perpajakan diharapkan dapat mewujudkan institusi perpajakan yang kuat, kredibel dan akuntabel yang mempunyai proses bisnis yang efektif dan efisien, membangun sinergi yang optimal antar lembaga, meningkatkan kepatuhan Wajib Pajak, dan meningkatkan penerimaan negara.

Beberapa penelitian-penelitian terdahulu yang membahas mengenai penerapan sistem e-filing salah satunya adalah Muturi dan Kieri (2015) yang menyatakan bahwa penerapan system e-filing berpengaruh terhadap kepatuhan wajb pajak, sedangkan hasil penelitian yang dilakukan oleh Tambun (2017) menyatakan bahwa penerapan sistem e-filing tidak berpengaruh terhadap kepatuhan wajib pajak

Penelitian terkait dengan pengetahuan perpajakan, Oladipupo dan Obazee (2016) menyatakan bahwa pengetahuan perpajakan berpengaruh positif dan signifikan terhadap kepatuhan wajib pajak. Tetapi hal ini bertentangan dengan Arahman (2012) yang menyatakan bahwa pengetahuan perpajakan tidak ditemukan pengaruh yang signifikan terhadap kepatuhan wajib pajak.

Selanjutnya penelitian mengenai kesadaran wajib pajak, Santoso (2016) menyatakan bahwa kesadaran wajib pajak berpengaruh positif dan signifikan terhadap kepatuhan wajib pajak, berbeda dengan penelitian yang dilakukan oleh Nugroho (2016) yang menyatakan bahwa kesadaran perpajakan secara parsial tidak berpengaruh terhadap kepatuhan perpajakan. Tujuan dalam penelitian ini adalah untuk mengetahui pengaruh penerapan e-filing, pengetahuan perpajakan, dan kesadaran wajib pajak terhadap kepatuhan wajib pajak.

\section{KAJIAN TEORI}

\section{Teory of Planned behavior (TPB)}

Theory of planned behavior (TPB) merupakan pengembangan dari Theory of Reasoned Action (TRA) yang dikemukakan oleh Fishbein dan Ajzen (1975) didsasarkan kepada asumsi bahwa manusia berperilaku dengan cara yang sadar, dengan mempertimbangkan informasi yang tersedia dan juga mempertimbangkan implikasi-implikasi dari tindakan yang dilakukan.

Menurut TRA, niat merupakan faktor yang memengaruhi terjadinya suatu tindakan (Ajzen dan Fishbein, 1975). Niat dipengaruhi oleh dua faktor 
dasar, yaitu faktor pribadi berupa sikap dan faktor pengaruh sosial yaitu norma subyektif, kemudian TPB menambahkan konstruk yang belum ada dalam TRA, yaitu persepsi kontrol keprilakuan (perceived behavioral control).

\section{Self Assesment System}

Menurut Mardiasmo (2016), self assessment system adalah suatu sistem pemungutan pajak yang memberi wewenang kepada Wajib Pajak untuk menentukan sendiri besarnya pajak terutang. Sedangkan menurut Rahayu (2017), self assessment system adalah suatu sistem perpajakan yang memberi kepercayaan kepada Wajib Pajak untuk memenuhi dan melaksanakan sendiri kewajiban dan hak perpajakannya. Kewajiban Wajib Pajak dalam self assessment system (Rahayu, 2017):

1. Mendaftarkan diri ke kantor Kantor Pelayanan

Pajak (KPP),

2. Menghitung Pajak oleh Wajib Pajak,

3. Membayar Pajak dilakukan sendiri oleh Wajib Pajak.

\section{Wajib Pajak}

Menurut UU No 28 Tahun 2007 tentang Ketentuan Umum dan Tata Cara Perpajakan, Wajib Pajak adalah orang pribadi atau badan, meliputi pembayar pajak, pemotong pajak, dan pemungut pajak, yang mempunyai hak dan kewajiban perpajakan sesuai dengan ketentuan peraturan perundang-undangan perpajakan.

Begitu juga menurut Suandy (2016), wajib pajak adalah orang pribadi atau badan yang menurut ketentuan peraturan perundang-undangan perpajakan ditentukan untuk melakukan kewajiban perpajakan termasuk pemungut atau pemotong pajak. Mardiasmo (2016) mendefinisikan wajib pajak adalah orang pribadi atau badan yang telah memenuhi kewajiban subjektif dan objektif. Wajib Pajak terdiri dari:

1. Wajib Pajak Orang Pribadi:

a. Wajib Pajak Orang Pribadi Yang Mempunyai Penghasilan Dari Usaha.

b. Wajib Pajak Orang Pribadi Yang Mempunyai Penghasilan Dari Pekerjaan Bebas.

c. Wajib Pajak Orang Pribadi Yang Mempunyai Penghasilan Dari Pekerjaan.

2. Wajib Pajak Badan :

a. Badan milik Pemerintah (BUMN dan BUMD)

b. Badan milik Swasta (PT, CV, Koperasi, Lembaga dan Yayasan)

c. Bentuk Usaha Tetap (BUT)
3. Wajib Pajak Bendahara sebagai pemungut dan pemotong pajak :
a. Bendahara Pemerintah Pusat.
b. Bendahara Pemerintah Daerah.
c. Bendahara Pemerintah Desa (Bendahara Desa).
d. Badan Layanan Umum (BLU).
e. Badan Layanan Umum Daerah (BLUD)

\section{Kesadaran Wajib Pajak}

Menurut Rahayu (2017), kesadaran wajib pajak merupakan suatu kondisi dimana wajib pajak mengerti dan memahami arti, fungsi maupun tujuan pembayaran pajak kepada negara. Dengan kesadaran wajib pajak yang tinggi akan memberikan pengaruh kepada meningkatkan kepatuhan pajak yang lebih baik lagi.

Suandy (2016), menyatakan bahwa kesadaran wajib pajak artinya wajib pajak mau dengan sendirinya melakukan kewajiban perpajakannya seperti mendaftarkan diri, menghitung, membayar dan melaporkan jumlah pajak terutangnya.

Kesadaran membayar pajak selain menimbulkan kepatuhan pajak dapat pula menumbuhkan sikap kritis dalam menyikapi masalah perpajakan, seperti kebijakan-kebijakan pajak yang ditetapkan pemerintah. Sehingga penerimaan utama negara dikelola negara dengan transparan dan akuntabel untuk kesejahteraan rakyat (Rahayu, 2017).

Tingginya tingkat kesadaran wajib pajak dapat dilihat dari:

1. Target penerimaan pajak tercapai

2. Tingkat kepatuhan pajak tinggi

3. Tax Ratio tinggi

4. Jumlah wajib pajak meningkat sejalan dengan jumlah masyarakat usia produktif

5. Jumlah tagihan pajak rendah

6. Tingkat pelanggaran rendah

\section{Pengetahuan Perpajakan}

Menurut Mardiasmo (2016) menayatakan bahwa pengetahuan pajak adalah kemampua wajib pajak dalam mengetahui peraturan perpajakan baik itu soal tarif pajak yang akan mereka bayar berdasarkan undang-undang maupun manfaat pajak yang akan berguna bagi kehidupan mereka.

Pengertian pengetahuan pajak menurut Carolina (2009) adalah informasi yang dapat digunakan wajib pajak sebagai dasar bertindak, mengambil keputusan, dan untuk menempuh arah atau strategi tertentu sehubungan dengan pelaksanaan hak dan kewajibannya dibidang perpajakannya.

Konsep pengetahuan pajak menurut Rahayu 
(2017) yaitu wajib pajak harus meliputi:

a. Pengetahuan mengenai Ketentuan Umum dan Tata Cara Perpajakan.

b. Pengetahuan mengenai sistem perpajakn di Indonesia.

c. Pengetahuan menegenai fungsi perpajakan.

Pengetahuan tentang pajak dapat dilihat dari pengetahuan yang menyangkut cara melaksanakan kewajiban pajak, siapa yang dikenakan, apa yang dikenakan, berapa besarnya, dan bagaimana cara menghitungnya (Supramono dan Damayanti, 2010).

\section{E-filing}

Direktorat Jenderal Pajak mendefinisikan bahwa e-Filing adalah cara penyampaian Surat Pemberitahuan (SPT) secara elektronik yang dilakukan secara online dan real time melalui internet pada website Direktorat Jenderal Pajak (http:// www.pajak.go.id) atau Penyedia Layanan SPT Elektronik atau Application Service Provider (ASP).

Menurut Rahayu (2017) aplikasi e-filing adalah aplikasi online yang digunakan wajib pajak dalam menyampaikan elektronik SPT (e-SPT) ke DJP melalui website resmi DJP, dengan registrasi terlebih dahulu untuk mendapatkan $e F I N$, karena melalui sitem online sehingga bersifat real time bagi DJP sebagai destinasi informasi.

Manfaat $e$-filing antara lain :

1. Lapor Pajak Dari Mana Saja, Kapan Saja,

2. Hemat Waktu,

3. Bukti Lapor Tak Mudah Hilang,

4. Terhindar dari Risiko Keterlambatan.

\section{Kepatuhan Wajib Pajak}

Menurut Gunadi (2013) pengertian kepatuhan wajib pajak diartikan bahwa wajib pajak mempunyai kesediaan untuk memenuhi kewajiban perpajakannya sesuai dengan aturan yang berlaku tanpa perlu diadakan pemeriksaan, investigasi seksama, peringatan ataupun ancaman dan penerapan sanksi baik hukum maupun administrasi. Pohan (2013) juga berpendapat bahwa kepatuhan wajib pajak berhubungan dengan kegiatan untuk mematuhi aturan perpajakan yang meliputi: administrasi, pembukuan, pemotongan/pemungutan pajak, penyetoran, pelaporan, memberikan data untuk keperluan pemeriksaan pajak, dan sebagaianya.

Rahayu (2017) membagi kepatuhan perpajakan menjadi dua macam yaitu :

1. Kepatuhan perpajakan formal :

a. Tepat waktu dalam mendaftarkan diri untuk memperoleh NPWP maupun untuk ditetapkan memperoleh NPPKP. b. Tepat waktu dalam menyetorkan pajak yang terutang.

c. Tepat waktu dalam melaporkan pajak yang sudah dibayar dan perhitungan perpajakannya.

2. Kepatuhan perpajakan material :

a. Tepat dalam menghitung pajak terutang sesuai dengan peraturan perpajakan.

b. Tepat dalam memperhitungkan pajak terutang sesuai dengan peraturan perpajakan.

c. Tepat dalam memotong maupun memungut pajak (Wajib Pajak sebagai pihak ketiga).

Putra (2015) meneliti tentang Pengaruh Penerapan Sistem e-Filling terhadap Kepatuhan Wajib Pajak dengan Pemahaman Internet sebagai Variabel Pemoderasi pada KPP Pratama Klaten, hasil dari penelitiannya menunjukkan bahwa Penerapan Sistem E-Filling berpengaruh terhadap Kepatuhan Wajib Pajak. Tetapi hasil penelitian tersebut berbeda dengan hasil penelitian yang dilakukan oleh Tambun (2016), menyatakan bahwa penerapan sistem $e$ filing tidak berpengaruh signifikan terhadap kepatuhan wajib pajak.

Oladipupo dan Obazee (2016) meneliti tentang Tax Knowledge, Penalties and Tax Compliance in Small and Medium Scale Enterprises in Nigeria. Hasil penelitian menunjukkan bahwa pengetahuan pajak berpengaruh positif signifikan terhadap kepatuhan pajak. Penelitian yang dilakukan oleh Fitrianingsih (2018) memiliki hasil penelitian yang berbeda, menyatakan bahwa pengetahuan perpajakan tidak berpengaruh terhadap kepatuhan wajib pajak.

Wulandari Agustiningsih (2016) meneliti Pengaruh Penerapan E-Filing, Tingkat Pemahaman Perpajakan Dan Kesadaran Wajib Pajak Terhadap Kepatuhan Wajib Pajak Di Kpp Pratama Yogyakarta. Hasil peneitiannya menunjukan bahwa Kesadaran wajib pajak berpengaruh positif dan signifikan terhadap kepatuhan wajib pajak. Sedangkan, penelitian yang dilakukan oleh Nugroho (2016), menyatakan bahwa kesadaran wajib pajak tidak berpengaruh terhadap kepatuhan wajib pajak.

\section{METODE PENELITIAN}

Jenis penelitian ini, merupakan penelitian kausal yaitu penelitian untuk mengetahui pengaruh satu atau lebih variabel terhadap variabel tertentu yang bersifat sebab akibat. Dalam penitian ini terdapat dua variabel, diantaranya: variabel bebas (independen variabel), variabel yang mempengaruhi yaitu penerapan e-filing, pengetahuan perpajkan, dan kesadaran wajib pajak atau $\mathrm{X}$, variabel yang di pengaruhi yaitu kepatuhan 
wajib pajak atau Y.

\section{Operasional Variabel}

a. Penerapan Sistem e-filing

Diukur dengan mengadopsi instrumen Agustiningsih (2016) yang telah disesuaikan dengan topik penelitian dengan menggunakan skala likert 15 untuk mengukur jawaban dari responden yang berupa pernyataan sangat tidak setuju, tidak setuju, setuju, dan sangat setuju.

\section{b. Pengetahuan Perpajakan}

Variabel ini diukur dengan mengadopsi instrumen Khasanah (2014) yang telah disesuaikan dengan topik penelitian dengan menggunakan skala likert 1-5 untuk mengukur jawaban dari responden yang berupa pernyataan sangat tidak setuju, tidak setuju, setuju, dan sangat setuju.

\section{c. Kesadaran Wajib Pajak}

Diukur dengan mengadopsi instrument Handayani, Faturokhman, Pratiwi (2012) yang telah disesuaikan dengan topik penelitian dengan menggunakan skala likert 1-5 untuk mengukur jawaban dari responden yang berupa pernyataan sangat tidak setuju, tidak setuju, setuju, dan sangat setuju.

\section{Populasi dan Sampel}

Populasi dalam penelitian ini adalah Wajib Pajak Orang Pribadi yang melakukan kegiatan usaha bebas di Bintaro Trade Center yang berjumlah 195. Sampel yang digunakan dalam penelitian ini adalah purposive sampling dengan menggunakan rumus Issac dan Michael, sebagai berikut :

$$
\mathrm{S}=\frac{\lambda^{2} \mathrm{NP}(1-\mathrm{P})}{\mathrm{d}^{2}(\mathrm{~N}-1)+\lambda^{2} \mathrm{P}(1-\mathrm{P} ;}
$$

$\mathrm{S}=$ Ukuran sampel yang diperlukan

$\mathrm{N}=$ Jumlah anggota populasi

$\mathrm{P}=$ Proporsi populasi 0,50

$\mathrm{d}=$ Tingkat akurasi 0,05

$\lambda^{2}=$ Tabel nilai chi-square sesuai tingkat

kepercayaan 3,841

$$
\begin{aligned}
& S=\frac{3,841 \cdot 193 \cdot 0,50(1-0,50)}{0,05^{2}(193-1)+3,841 \cdot 0,50(1-0,50 ;}, \\
& S=128,6778337
\end{aligned}
$$

Maka jumlah sampel yang diambil pada penelitian ini adalah 128,6778337 yang dibulatkan menjadi 130 responden.

\section{Teknik Pengumpulan Data}

Teknik yang digunakan dalam melaksanakan penelitian ini adalah:
1. Tinjauan kepustakaan (library research)

Memhami teori-teori dan konsep-konsep yang berhubungan dengan topik pembahasan penelitian dengan cara membaca dan mengkaji dari lieratur, jurnal, buku-buku, atau tulisan ilmiah dari para ahli yang bertujuan untuk memperoleh landasan teori.

2. Penelitian Lapangan (Field Research)

Dalam hal ini peneliti menyebarkan kuesioner yang ditujukan kepada usahawan yang menjalankan usahanya di Bintaro Trade Center.

\section{Metode Analisis}

Analisis data yang digunakan antara lain adalah : 1) analisis statistik deskriptif untuk melihat nilai maksimal, minimal, rata-rata dan juga standar deviasi dari data yang diuji; 2) Uji kualitas data yang terdiri dari uji validitas untuk mengukur sah atau valid tidaknya kuesioner dan uji reliabilitas mengetahui sejauh mana hasil pengukuran dapat dipercaya bila dilakukan pengukuran pada waktu yang berbeda pada kelompok subjek yang sama ; 3) Uji asumsi klasik yang terdiri dari uji normalitas, uji multikolinieritas, dan uji heterokedastisita data diuji dengan aplikasi SPSS versi 22; 4) Uji koefisien determinasi (R2) untuk mengukur seberapa jauh kemampuan model dapat menjelaskan variasi variabel dependen; 5) Uji statistik F untuk mengetahui pengaruh variabel bebas secara keseluruhan terhadap variabel terikatnya; 6) Uji signifikansi parameter individual (uji t)untuk mengetahui secara parsial pengaruh dari variabel bebas terhadap variabel terikatnya; 7) Uji analisis regresi berganda untuk menguji hubungan pengaruh antara satu variabel terhadap variabel lain.

\section{HASIL DAN PEMBAHASAN}

\section{Analisis Statistik Deskriptif}

Data responden dalam penelitian ini yang memenuhi kriteria berjumlah 90 responden.

Tabel 1 Analisis Deskriptif, sebagai berikut:

Tabel 1. Analisis Deskriptif Descriptive Statistics

\begin{tabular}{|l|c|c|c|c|c|}
\hline \multicolumn{1}{|c|}{ Descriptive Statistics } \\
& N & Minimum & Maximum & Mean & $\begin{array}{c}\text { Std. } \\
\text { Deviation }\end{array}$ \\
\hline PSE_X1 & 90 & 4 & 15 & 12,77 & 2,023 \\
PP_X2 & 90 & 5 & 15 & 12,49 & 1,915 \\
KSWP_X3 & 90 & 3 & 15 & 12,43 & 1,955 \\
KPWP Y & 90 & 5 & 15 & 12,77 & 1,902 \\
Valid N (listwise) & 90 & & & & \\
\hline
\end{tabular}

Sumber : Output mengguanakan SPSS 22, 2018

Dari hasil analisa data, diperoleh nilai minimum dan maksimum yang didapat total variabel penerapan 
sistem e-filing adalah 4 dan 15, sedangkan rata rata (mean) dan standar devasi secara berturut turut adalah 12,77 dan 2,023. Variabel pengetahuan perpajakan, dari hasil analisa data menunjukkan nilai minimum dan maksimum sebesar 5 dan 15, sedangkan rata - rata (mean) dan standar devasi secara berturut - turut adalah 12,49 dan 1,915. Variabel kesadaran wajib pajak, diperoleh menunjukkan nilai minimum dan maksimum sebesar 3 dan 15, sedangkan rata - rata (mean) dan standar devasi secara berturut - turut adalah 12,43 dan 1,955. Variabel kepatuhan wajib pajak menunjukkan nilai minimum dan maksimum sebesar 5 dan 15, sedangkan rata - rata (mean) dan standar devasi secara berturut - turut adalah 12,77 dan 1,902.

\section{Uji Validitas}

Dalam uji validitas, kuesioner dinyatakan valid dilihat dari Corrected Item-Total Correlation masing-masing pertanyaan. Jika $r$ hitung e $r$ tabel, maka pertanyaan dinyatakan valid dan jika $r$ hitung $<\mathrm{r}$ tabel, maka pertanyaan dinyatakan tidak valid. Nilai $r$ tabel dapat diperoleh melalui df (degree of freedom) dan á $=0,05$. Dalam penelitian ini nilai rtabel yang didapat adalah 0,2072 dimana $\mathrm{Df}=90-2$ $=88$.

Tabel 2. Hasil Uji Validitas Variabel Penerapan Sistem $e$-filing (X1)

\begin{tabular}{|c|c|c|c|}
\hline $\begin{array}{c}\text { Item } \\
\text { Pertanyaan }\end{array}$ & $\begin{array}{c}\text { Pearson } \\
\text { Correlation }\end{array}$ & $\mathbf{R}_{\text {tabel }}$ & Keterangan \\
\hline PSE 1 & 0,797 & 0,2072 & Valid \\
\hline PSE 2 & 0,797 & 0,2072 & Valid \\
\hline PSE 3 & 0,847 & 0,2072 & Valid \\
\hline
\end{tabular}

Sumber: Output menggunakan SPSS 22, 2018

Dari table 2, dapat disimpulkan bahwa setiap item pertanyaan menunujukkan $r$ hitung $>r$ tabel, maka dapat dikatakan bahwa setiap item pertanyaan tersebut valid.

Tabel 3. Hasil Uji Validitas Variabel Pengetahuan Perpajakan (X2)

\begin{tabular}{|c|c|c|c|}
\hline $\begin{array}{c}\text { Item } \\
\text { Pertanyaan }\end{array}$ & $\begin{array}{c}\text { Pearson } \\
\text { Correlation }\end{array}$ & $\mathbf{R}_{\text {tabel }}$ & Keterangan \\
\hline PP 1 & 0,832 & 0,2072 & Valid \\
\hline PP 2 & 0,815 & 0,2072 & Valid \\
\hline PP 3 & 0,764 & 0,2072 & Valid \\
\hline
\end{tabular}

Sumber : Output menggunakan SPSS 22, 2018

Dari tabel 3 dapat disimpulkan bahwa setiap item pertanyaan menunujukkan $r$ hitung $>r$ tabel, maka dapat dikatakan bahwa setiap item pertanyaan tersebut valid.
Tabel 4. Hasil Uji Validitas Variabel Kesadaran Wajib Pajak (X3)

\begin{tabular}{|c|c|c|c|}
\hline $\begin{array}{c}\text { Item } \\
\text { Pertanyaan }\end{array}$ & $\begin{array}{c}\text { Pearson } \\
\text { Correlation }\end{array}$ & $\mathbf{R}_{\text {tabel }}$ & Keterangan \\
\hline KSWP 1 & 0,788 & 0,2072 & Valid \\
\hline KSWP 2 & 0,786 & 0,2072 & Valid \\
\hline KSWP 3 & 0,861 & 0,2072 & Valid \\
\hline
\end{tabular}

Sumber : Output menggunakan SPSS 22, 2018

Dari tabel 4, dapat disimpulkan bahwa setiap item pertanyaan menunujukkan $r$ hitung $>r$ tabel, maka dapat dikatakan bahwa setiap item pertanyaan tersebut valid.

Tabel 5. Hasil Uji Validitas Variabel Kepatuhan Wajib Pajak (Y)

\begin{tabular}{|c|c|c|c|}
\hline $\begin{array}{c}\text { Item } \\
\text { Pertanyaan }\end{array}$ & $\begin{array}{c}\text { Pearson } \\
\text { Correlation }\end{array}$ & $\mathbf{R}_{\text {tabel }}$ & Keterangan \\
\hline KPWP 1 & 0,816 & 0,2072 & Valid \\
\hline KPWP 2 & 0,822 & 0,2072 & Valid \\
\hline KPWP 3 & 0,805 & 0,2072 & Valid \\
\hline
\end{tabular}

Sumber : Output menggunakan SPSS 22, 2018

Dari tabel 5 dapat disimpulkan bahwa setiap item pertanyaan menunujukkan $r$ hitung $>r$ tabel, maka dapat dikatakan bahwa setiap item pertanyaan tersebut valid.

\section{Uji Reliabilitas}

Tabel 6. Hasil Uji Reliabilitas

\begin{tabular}{|l|c|c|}
\hline \multicolumn{1}{|c|}{ Variabel } & $\begin{array}{c}\text { Cronbach's } \\
\text { Alpha }\end{array}$ & Keterangan \\
\hline $\begin{array}{l}\text { Penerapan } \\
\text { Sistem } \text { - } \\
\text { filing(X1) }\end{array}$ & 0,745 & Reliabel \\
\hline $\begin{array}{l}\text { Pengetahuan } \\
\text { Perpajakan } \\
\text { (X2) }\end{array}$ & 0,725 & Reliabel \\
\hline $\begin{array}{l}\text { Kesadaran } \\
\text { Wajib Pajak } \\
\text { (X3) }\end{array}$ & 0,742 & Reliabel \\
\hline $\begin{array}{l}\text { Kepatuhan } \\
\text { Wajib Pajak } \\
\text { (Y) }\end{array}$ & 0,743 & Reliabel \\
\hline
\end{tabular}

Sumber : Output menggunakan SPSS 22, 2018.

Tabel 6 menunjukkan nilai Cronbach's Alpha setiap variabel secara berturut-turut sebagai berikut: penerapan sistem e-filing memiliki Cronbach's Alpha 0,745 lebih besar dari 0,70, pengetahuan perpajakan memiliki nilai Cronbach's Alpha 0,725 lebih besar dari 0,70, kesadaran wajib pajak memiliki nilai Cronbach's Alpha 0,742 lebih besar dari 0,70, dan kepatuhan wajib pajak memiliki nilai Cronbach's Alpha 0,743 lebih besar dari 0,70. Sehingga dapat disimpulkan bahwa hasil pengukuran ketiga variabel diatas adalah konsisten dapat dipercaya untuk digunakan dalam penelitian. 


\section{Uji Residual}

Tabel 7. Hasil Uji Residual One-Sample Kolmogorov-Smirnov Test

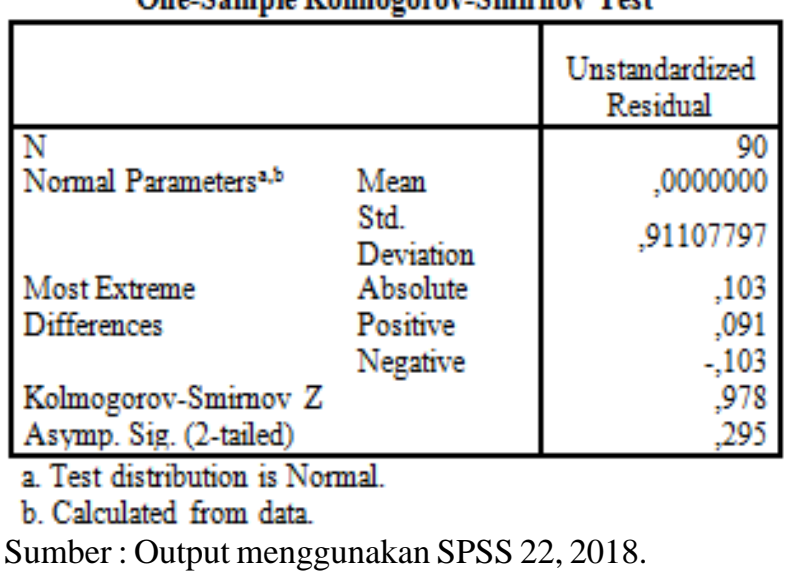

Dari tabel 7 menunjukkan nilai KolmogrovSmirnov Z sebesar 0,978 dengan signifikansi 0,295 dan lebih besar dari 0,05, maka dapat disimpulkan bahwa data dalam penelitian ini setelah residual terdistribusi normal.

\section{Uji Multikolonieritas}

Nilai cut off yang umum dipakai untuk menunjukkan adanya multikolonieritas adalah nilai Tolerance d" 0,10 atau sama dengan nilai VIF e" 10 (Ghozali, 2013).

Penerapan sistem e-filing (X1) memiliki tolerance sebesar 0,116 lebih besar dari 0,10 $(>0,10)$ dan nilai VIF sebesar 8,634 lebih kecil dari 10,00 $(<10,00)$. Dari uraian tersebut dapat disimpulkan bahwa variabel Penerapan Sistem e-filing (X1) tidak terdapat multikolinieritas.

Pengetahuan Perpajakan (X2) memiliki tolerance sebesar 0,141 lebih besar dari 0,10 $(>0,10)$ dan nilai VIF sebesar 7,067 lebih kecil dari 10,00 $(<10,00)$. Dari uraian tersebut dapat disimpulkan bahwa variabel Pengetahuan Perpajakan (X2) tidak terdapat multikolinieritas.

Kesadaran Wajib Pajak (X3) memiliki tolerance sebesar 0,219 lebih besar dari 0,10 $(>0,10)$ dan nilai VIF sebesar 4,576 lebih kecil dari 10,00 $(<10,00)$. Dari uraian tersebut dapat disimpulkan bahwa variabel Kesadaran Wajib Pajak (X3) tidak terdapat multikolinieritas.

\section{Uji Heterokedasitas}

Dalam penelitian ini uji heteroskedastisitas menggunakan metode Uji Glesjer. Uji Glesjer adalah meregresikan antara variabel bebas dengan variabel residual absolute, dimana apabila $\mathrm{p}>0,05$ maka variabel bersangkutan dinyatakan bebas heteroskedastisitas.
Tabel 8. Hasil Uji Glesjer Coefficients $^{2}$

\begin{tabular}{|c|c|c|c|c|c|c|}
\hline \multirow{2}{*}{\multicolumn{2}{|c|}{ Model }} & \multicolumn{2}{|c|}{$\begin{array}{l}\text { Unstandardized } \\
\text { Coefficients }\end{array}$} & \multirow{2}{*}{$\begin{array}{c}\begin{array}{l}\text { Standardized } \\
\text { Coefficients }\end{array} \\
\text { Beta }\end{array}$} & \multirow[t]{2}{*}{$t$} & \multirow[t]{2}{*}{ Sig. } \\
\hline & & B & Std. Error & & & \\
\hline \multirow{4}{*}{1} & (Constant) & .337 & .434 & & .776 & .440 \\
\hline & PSE_Xl & .030 & .093 & .101 & .319 & .750 \\
\hline & PP_X2 &. .006 & .089 & -.020 & -.071 & .943 \\
\hline & KSWP_X3 & .004 & .070 & .013 & .055 & .956 \\
\hline
\end{tabular}

Hasil uji glesjer pada tabel 8, menunjukkan bahwa nilai signifikansi setiap variabel lebih besar dari 0,05 , maka dapat disimpulkan bahwa tidak terjadi heteroskedastisitas pada model regresi.

\section{Uji Koefisien Determinasi $\left(R^{2}\right)$}

Tabel 9. Hasil Uji Koefisien Determinasi $\left(\mathrm{R}^{2}\right)$

\begin{tabular}{|c|c|c|c|c|}
\hline \multicolumn{5}{|c|}{ Model Summary ${ }^{b}$} \\
\hline Model & $R$ & R Square & $\begin{array}{c}\text { Adjusted } R \\
\text { Square }\end{array}$ & \begin{tabular}{|l|} 
Std. Error of \\
the Estimate
\end{tabular} \\
\hline 1 & $.878^{a}$ & .771 & .763 & .927 \\
\hline
\end{tabular}

Besarnya adjusted R2 adalah 0,763, hal ini berarti 76,3\% variabel kepatuhan wajib pajak dapat dijelaskan oleh ketiga variabel independen penerapan sistem e-filing, pengetahuan perpajakan, dan kesadaran wajib pajak. Sedangkan sisanya (100\% $76,3 \%=23,7 \%$ ) dijelaskan oleh sebab- sebab yang lain diluar model. Standar Error of Estimate (SEE) sebesar 0,927. Dimana semakin kecil nilai SEE, maka akan membuat model regresi semakin tepat dalam memprediksi variabel dependen.

\section{Uji Analisis Linier Berganda}

Dalam penelitian ini menunjukkan data yang digunakan dalam penelitian ini telah memenuhi asumsi klasik, yaitu data terdistribusi normal, tidak ada gejala multikolonieritas, dan tidak ada gejala heteroskedastisitas dengan demikian dapat disimpulkan bahwa model regresi yang digunakan dalam penelitian ini telah memenuhi model estimasi yang Best Linier Unbiased Estimator (BLUE) dan layak untuk dilakukan analisis regresi (Ghozali, 2013).

Berdasarkan tabel 4.16 dapat diketahui bahwa nilai koefisien dari persamaan regresi dari output tersebut didapatkan model persamaan regresi sebagai berikut:

$$
\mathrm{Y}=\mathrm{a}+\mathrm{a} 1 \mathrm{x} 1+\mathrm{a} 2 \mathrm{x} 2+\text { â3x3 }
$$

$\mathrm{KPWP}=1,789+0,491 \mathrm{PSE}+0,162 \mathrm{PP}+0,216 \mathrm{KSWP}$ 
Keterangan:

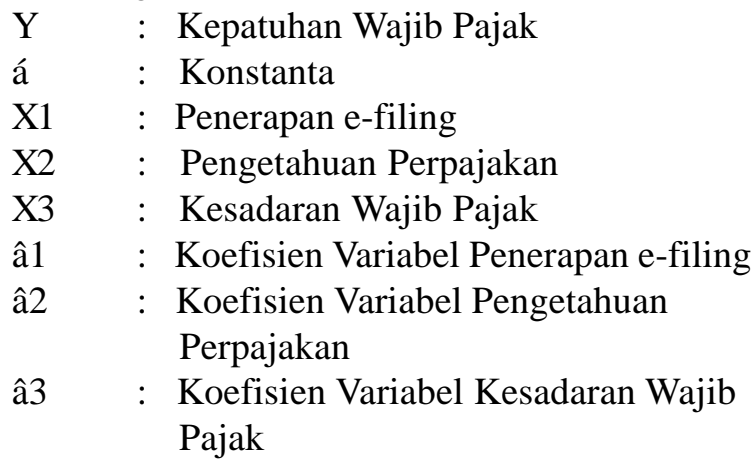

\section{a. Pengaruh Penerapan Sistem e-filing Terhadap Kepatuhan Wajib Pajak}

Hasil uji hipotesis penerapan sistem e-filing menunjukkan bahwa nilai signifikansi variabel penerapan sistem $e$-filing sebesar 0,001 lebih kecil dari tingkat signifikansi 0,05 dan t hitung 3,439 lebih besar dari t tabel 1,987. Artinya variabel penerapan sistem $e$-filing berpengaruh terhadap kepatuhan wajib pajak. Hal ini telah sesuai dengan hipotesis penelitian dimana peneliti membuat hipotesis bahwa penerapan sistem e-filing berpengaruh terhadap kepatuhan wajib pajak.Dengan diberlakukannya kewajiban menyampaikan SPT melalui $e$-filing diharapkan kepatuhan wajib pajak semakin meningkat. Keberhasilan penerapan sistem $e$-filing dapat dilihat dari persepsi wajib pajak dalam menggunakan $e$-filing. Jika wajib pajak semakin puas dalam menggunakan sistem $e$-filing secara tidak langsung akan membuat wajib pajak akan semakin patuh. Jadi dapat disimpulkan bahwa semakin baik penerapan $e$ - filing maka kepatuhan wajib pajak akan semakin meningkat. Hasil penelitian ini konsisten dengan penelitian yang dilakukan oleh Agustiningsih (2016), Putra (2015), Muturi dan Kieri (2015) yang menunjukkan bahwa penerapan sistem $e$-filing berpengaruh terhadap kepatuhan wajb pajak. Penelitian ini semakin memperkuat penelitian sebelumnya bahwa penerapan sistem e-filing berpengaruh terhadap kepatuhan wajib pajak.

\section{b. Pengaruh Pengetahuan Perpajakan Terhadap Kepatuhan Wajib Pajak}

Hasil uji hipotesis pengetahuan perpajakan menunjukkan bahwa nilai signifikansi variabel pengetahuan perpajakan sebesar 0,239 lebih besar dari tingkat signifikansi 0,05 dan t hitung 1,186 lebih kecil dari ttabel 1,987. Artinya variabel pengetahuan perpajakan tidak berpengaruh terhadap kepatuhan wajib pajak. Hasil penelitian ini tidak sesuai dengan hipotesis penelitian dimana peneliti membuat hipotesis bahwa pengetahuaan perpajakan berpengaruh terhadap kepatuhan wajib pajak. Hal ini menunjukkan berarti semakin rendah tingkat pengetahuan perpajakan bagi wajib pajak maka akan semakin menurunnya tingkat kepatuhan wajib pajak. Pengetahuan perpajakan berkaitan dengan pemahaman wajib pajak terkait ketentuan undangundang yang berlaku, karena proses administrasi perpajakan mulai dari proses perhitungan sampai dengan proses pelaporan mengacu pada ketentuan undang-undangan perpajakan yang berlaku. Sosialisasi yang dilakukan oleh Direktorat untuk lebih mendalami peraturan perundang-undangan yang berlaku agar wajib pajak dapat melaksanakan kewajiban perpajakkannya dengan baik. Hasil penelitian ini konsisten dengan penelitian yang dilakukan oleh Arrahman (2012) dan Fitrianingsih (2018) yang menyatakan bahwa pengetahuan perpajakan tidak berpengaruh terhadap kepatuhan wajib pajak. Tetapi hasil penelitian ini tidak konsisten dengan Olugoke dan Obazee (2016), Khasanah (2016), Nugroho (2016) yang menyatakan bahwa pengetahuan perpajakan berpengaruh terhadap kepatuhan wajib pajak.

\section{c. Pengaruh Kesadaran Wajib Pajak Terhadap Kepatuhan Wajib Pajak}

Hasil uji hipotesis pengaruh kesadaran wajib pajak menunjukkan bahwa nilai signifikansi variabel penerapan sistem $e$-filing sebesar 0,047 lebih kecil dari tingkat signifikansi 0,05 dan thitung 2,014 lebih besar dari ttabel 1,987. Artinya variabel kesadaran wajib pajak berpengaruh terhadap kepatuhan wajib pajak. Hal ini telah sesuai dengan hipotesis penelitian dimana peneliti membuat hipotesis bahwa kesadaran wajib pajak berpengaruh terhadap kepatuhan wajib pajak. Kesadaran wajib pajak berkaitan dengan peran aktif wajib pajak dalam melaksanakan kewajiban perpajakannya secara sukarela tanpa adanya paksaan dari pihak manapun, selain itu kesadaran wajib pajak juga merupakan kondisi dimana wajib pajak mengerti dan memahami arti, fungsi maupun tujuan pembayaran pajak kepada Negara. Jadi dapat disimpulkan bahwa dengan kesadaran wajib pajak yang tinggi akan memberikan pengaruh kepada peningkatan kepatuhan pajak yang lebih baik lagi. Hasil penelitian ini konsisten dengan hasil penelitian yang dilakukan Santoso (2016), Agustiningsih (2016), dan Khasanah (2014) menyatakan bahwa kesadaran wajib pajak berpengaruh terhadap kepatuhan wajib pajak. Penelitian ini semakin memperkuat penelitian sebelumnya bahwa kesadaran wajib pajak berpengaruh terhadap kepatuhan wajib pajak. 


\section{KESIMPULAN DAN SARAN}

\section{Kesimpulan}

a. Penerapan Sistem $e$-filing berpengaruh terhadap kepatuhan wajib pajak. Dengan diwajibkannya menyampaikan Surat Pemberitahuan (SPT) melalui $e$-filing sebagaimana yang telah diatur di dalam PMK-09/PMK.03/2018, tentu hal ini harus didukung dengan sistem yang baik. Semakin baik sistem pelaporan melalui e-filing maka kepatuhan wajib pajak akan semakin meningkat.

b. Pengetahuan Perpajakan tidak berpengaruh terhadap kepatuhan wajib. Hal ini mengindikasikan bahwa pengetahuan perpajakan wajib pajak masih rendah sehingga akan mempengaruhi penurunan tingkat kepatuhan wajib pajak. Pengetahuan perpajakan berkaitan dengan pemahaman wajib pajak terkait peraturan perundang-undangan perpajakan.

c. Kesadaran wajib pajak berpengaruh terhadap kepatuhan wajib pajak. Hal ini menunjukkan bahwa tingkat kesadran wajib pajak terhadap peran serta fungsi pajak yang tinggi sehingga akan memberikan pengaruh kepada peningkatan kepatuhan pajak yang lebih baik lagi.

\section{Saran}

a. Bagi Direktorat Jendaral Pajak untuk lebih meningkatkan sistem pelayanan e-filing dan kemudahan untuk mengakses, sehingga wajib pajak dapat merasakan kebermanfaatan diterapkannya pelaporan melalui e-filing dan secara tidak langsung akan meningkatkan kepatuhan wajib pajak. Selain itu, DJP dapat mengadakan kegiatan untuk meningkatkan kesadaran, dan melakukan penyuluhan atau sosialisasi mengenai pengetahuan perpajakan agar dapat mendorong wajib pajak dalam memenuhi angka kepatuhan pajak.

b. Bagi Wajib Pajak Orang Pribadi yang melakukan kegiatan usaha di BTC, untuk lebih berperan aktif dalam mempelajari dan memahami peraturan perundang-undangan perpajakan atau dapat menggunakan jasa konsultan pajak dalam pengadministrasian pajak dengan tujuan untuk meminimalisasi terjadinya kesalahan saat penyampaian kewajiban perpajakan.

c. Untuk peneliti selanjutnya diharapkan melakukan penelitian pada lingkup yang lebih luas, dan dapat menggunakan faktor internal dan eksternal lainnya dalam menentukan tingkat kepatuhan wajib pajak kareana adanya keterbatasan waktu dalam penelitian ini. Hal ini bertujuan untuk mengetahui seberapa besar pengaruh faktor-faktor lain terhadap kepatuhan Wajib Pajak Orang Pribadi.

\section{DAFTAR PUSTAKA}

Adimasu, Niway Ayalew. 2017. Tax Awareness And Perception Of Tax Payers And Their Voluntary Tax Compliance Decision: Evidence From Individual Tax Payers In Snnpr, Ethiopia. International Journal of Scientific and Research Publications, Volume 7. ISSN 2250-3153.

Agustiningsih, Wulandari. 2016. Pengaruh Penerepan EFiling, Tingkat Pemahaman Perpajakan dan Kesadaran Wajib Pajak Terhadap Kepatuhan Wajib Pajak Di KPP Pratama Yogyakarta. Jurnal Nominal: Vol.5 No.2. Universitas Negeri Yogyakarta.

Ajzen, I. 2005. Attitudes, personality, and behavior. New York: Open University Press.

Carolina, Veronica. 2009. Pengetahuan Pajak. Jakarta: Salemba Empat.

Direktorat Jenderal Pajak. Electronic Filing. http:// www.pajak.go.id/electronic-filing, diakses 29 Juli 2018.

Dwitama, Farhan. 2018. Puluhan ribu WP belum lapor SPT di KPP Pondok Aren. http:// news.metrotvnews.com/daerah/ybDOvoqNpuluhan-ribu-wp-belum-lapor-spt-di-kpp-pondokaren, di akses 29 Juli 2018.

Fitrianingsih, Fita. 2018.Analisis Pengaruh Pengetahuan Perpajakan, Pelayanan Fiskus Dan Sanksi Denda Terhadap Kepatuhan Wajib Pajak Dalam Membayar Pajak Bumi Dan Bangunan Perdesaan Dan Perkotaan Di Kota Pasuruan e-Journal Ekonomi Bisnis dan Akuntansi Vol.1. ISSN : 2355-4665.

Ghozali, Imam. 2013. Aplikasi Analisis Multivariate dengan Program IBM SPSS 21. Badan Penerbit: Universitas Diponegoro.

Gunadi. 2013. Panduan Komprehensif Pajak Penghasilan. Jakarta: Bee Media Indonesia.

Handayani, Sapti Wuri, Agus Faturokhman, dan Umi Pratiwi. 2012. Faktor-Faktor Yang Mempengaruhi Kemauan Membayar Pajak Wajib Pajak Orang Pribadi Yang Melakukan Pekerjaan Bebas. Simposium Nasional Akuntansi XV. Purwokerto.

Khasanah, Septiyani Nur. 2014. Pengaruh Pengetahuan Perpajakan, Modernisasi Sistem Administrasi Perpajakan, dan Kesadaran Wajib Pajak Terhadap Kepatuhan Wajib Pajak pada Kantor Wilayah Direktorat Jenderal Pajak Daerah Istimewa Yogyakarta Tahun 2013.

Mardiasmo. 2016. Perpajakan Edisi Revisi. Yogyakarta: Andi.

Mongwaketse. 2015. Perceived effects of an electronic filing system on tax compliance in a district municipality, South Africa. Business Administration in the Faculty of Commerce and Administration : Mafikeng Campus of the NorthWest University. 
Muturi, Harrison M., and Kiari, Nahashon. 2015. Effects Of Online Tax System On Tax Compliance Among Small Taxpayers In Meru Country, Kenya. International Journal of Economics, Commerce and Management : Nkabune Technical Training Institute.

Mahyarni. 2013. Theory of Reasoned dan Theory of Planned Behavior. Jurnal El-Riyasah Vol.4 No.1.

Nugroho, Aditya. 2016. Pengaruh Kesadaran Wajib Pajak Dan Pengetahuan Perpajakan Wajib Pajak Terhadap Kepatuhan Wajib Pajak Dalam Membayar Pajak Penghasilan (studi kasus pada KPP Semarang Candi). Journal Of Accounting, Vol.2 No.2

Olugoke, Adesina and Oyioghosa Obazee. 2016. Tax Knowledge, Penalties And Tax Compliance In Small And Medium Enterprises In Nigeria”. International Journal of Finance and Accounting : University of Benin, Benin City, Nigeria.

Peraturan Menteri Keuangan Nomor 192/PMK.03/2007 tentang Kriteria Wajib Pajak yang Dapat Diberikan Pengembalian Pendahuluan Kelebihan Pajak.

Peraturan Menteri Keuangan Nomor 09/PMK.03/2018 tentang Perubahan Atas Peraturan Menteri Keuangan Nomor 243/PMK.03/2014 tentang Surat Pemberitahuan (SPT).

Peraturan Presiden Republik Indonesia Nomor 40 Tahun 2018 tentang Pembaruan Sistem Administrasi Perpajakan.

Pohan, Chiril Anwar. 2013. Manajemen Perpajakan. Jakarta: Gramedia Pustaka Utama.

Prastowo, Yustinus. 2017. Modernisasi Administrasi Perpajakan : Upaya Penyempurnaan Pelayanan Pajak (I). https://www.online-pajak.com/ modernisasi-administrasi-perpajakan-upayapenyempurnaan-pelayanan-pajak-bagian-1-1, di akses 22 Mei 2018.

Puspa, Dian. 2018. Efiling Pajak : Panduan Lengkap Lapor Pajak Online Perusahaan. https://www.onlinepajak.com/efiling-pajak-online, diakses 29 Juli 2018.

Putra, Toma Yanuar. 2015. Pengaruh PenerapanSistem Administrasi E-Registration, E-Spt, Dan E-Filing Terhadap Tingkat Kepatuhan Wajib Pajak (Studi Pada Wajib Pajak Di Kantor Pelayanan Pajak Pratama Singosari).Jurnal Perpajakan: Vol.6 No.2. Universitas Brawijaya.

Rahayu, Siti Kurnia. 2017. Perpajakan Konsep \& Aspek Formal. Bandung: Rekayasa Sains.
Resmi, Siti. 2014. Perpajakan Teori dan Kasus. Jakarta: Salemba Empat.

S, Lidya Julita. 2018. Ditjen Pajak: Masih Banyak WP Lapor SPT Secara Manual. https:// economy.okezone.com/read/2018/03/12/20/ 1871366/ditjen-pajak-masih-banyak-wp-lapor-sptsecara-manual, diakses 26 Juli 2018.

Santoso, Sarah Nisa. 2015. Pengaruh Pengetahuan Pajak, Kesadaran Wajib Pajak, Dan Sanksi Pajak Terhadap Kepatuhan Wajib Pajak (Studi Pada Wajib Pajak Orang Pribadi Di Kantor Pelayanan Pajak Pratama Kepanjen). Jurnal Perpajakan : Vol.6 No.1.

Universitas Brawijaya.

Suandy, Erly. 2016. Hukum Pajak. Jakarta: Salemba Empat. Sugiyono. 2010. Metode Penelitian Kuantitatif Kualitatif \& RND. Bandung: Alfabeta.

Supramono, Damayanti Theresiadan. 2010. Perpajakan Indonesia, Mekanisme dan Perhitungan. Yogyakarta; Andi.

Tambun, Kartika Ratna Handayani Sihar. 2016. Pengaruh Penerapan Sistem E-Filing Dan Pengetahuan Perpajakan Terhadap Kepatuhan Wajib Pajak Dengan Sosialisasi Sebagai Variabel Moderating. Jurnal Akuntansi Perpajakan Vol. 1, No. 2. ISSN 2355-9993. Universitas 17 Agustus 1945 Jakarta.

Tohsun, Mehmet S., \& Pippin, Sonja E. 2014. Electronic Tax Filing in the United States: An Analysis of Possible Success factors. Electronic Journal of eGovernment Volume 12. College of Business Administration, University of Nevada.

Undang-Undang Nomor 28 Tahun 2007 tentang Ketentuan Umum dan Tata Cara Perpajakan.

Wati, Lela Nurlela. 2018. Metodologi Penelitian Terapan, Aplikasi SPSS, EVIEWS, Smart PLS, dan AMOS. Bandung: CV. Mujahid Press.

Wibowo. 2018. Pengertian Wajib Pajak. http:// www.wibowopajak.com/2012/01/pengertian-wajibpajak.html. diakses 06 Agustus 2018.

Wikamorys, Dian Anggraini dan Thinni Nurul Rochmach. 2017. Aplikasi theory of planned behavior dalam membangkitkan niat pasien untuk melakukan operasi katarak. Jurnal Administrasi Kesehatan Indonesia Vol.5 No.1. Fakultas Kesehatan Masyarakat Universitas Airlangga Surabaya.

Zaidi, Syed K.R., Henderson, Cassy D., and Gupta, Gauraf. 2017. The moderating effect of culture on e-filing taxes: evidence from India. Journal of Accounting in Emerging Economies Vol. 7 No. 1. 